\title{
Necrotizing Enterocolitis: Probiotics, Prebiotics and Synbiotics for Prevention in Preterm Infants
}

\author{
Tripathy $\mathbf{P K}^{1}$, Nanda $\mathbf{R}^{2}$ \\ ${ }^{1}$ Dr Prasanta Kumar Tripathy, Department of Pediatric Surgery, SVP Postgraduate Institute of Pediatrics, Cuttack, \\ Odisha, ${ }^{2}$ Dr Rachita Nanda, Department of Biochemistry, AIIMS, Raipur, Chhattisgarh, India.
}

Address for Correspondence: Dr Rachita Nanda, Email: dr.rachitananda@aiimsraipur.edu.in

\begin{abstract}
Necrotizing enterocolitis is a devastating disease of newborns associated with intestinal inflammation and necrosis. In spite of advances in neonatal care, intensive care units and refinement of surgical practices, the high mortality and long term morbidity due to NEC remains a challenge. The pathogenesis of the disease is complicated and not completely understood. Gradual development in the field of NEC revealed innate immune system, comprised of 'Toll-like receptors' (TLR) in the pathogenesis of the disease. TLR4 is an important member of TLR and is the receptor for bacterial lipopolysaccharide. Activation of TLR4 causes intestinal mucosal injury and decreased epithelial repair in premature neonates. Probiotics are live microorganisms and are rich in bacterial DNA. CpG motifs of DNA can inhibit TLR4 signaling and reduce NEC severity. Probiotics also modulate enterocyte genes that regulate innate immune-mediated inflammation, thereby preventing NEC. The above molecular basis is supported by multiple individual studies using probiotics especially Lactobacillus and Bifidobacteria for preventing NEC in preterm infants. Their encouraging results prompted us to carry out an analysis of major trials on probiotics along with considering pathophysiological and immunological aspects of the disease.
\end{abstract}

Prebiotics have a protective effect in NEC by stimulating colonization of beneficial bacteria in intestine. Products containing both probiotics and prebiotics (synbiotics) were also tried and they are found to be more beneficial than either probiotics or prebiotics. This review will highlight recent concepts and evidences on probiotics and prebiotics in preventing NEC in preterm, low birth weight infants.

Key words: Necrotizing Enterocolitis, Toll-like receptors, Probiotics, Prebiotics

\section{Introduction}

Necrotizing enterocolitis (NEC) is the most common gastrointestinal emergency in preterm neonates and affects 5 to $10 \%$ of infants $<1500 \mathrm{gm}$ [1]. Surgical intervention is required in $30 \%$ to $40 \%$ of cases [2]. Peritoneal drainage or laparotomy with resection of affected bowel is needed in infants with intestinal perforation or deteriorating clinical condition. Mortality due to NEC is reported as high as $40 \%$ and rises to $50 \%$ in those requiring surgical intervention [3]. Modern intensive care units and newborn care contributed towards increased survival of the neonates over last few decades. But the incidence and long term health problems in NEC is unchanged due to lack of systematic preventive strategy. Prematurity and low birth weights are two most common associations with the disease and are inversely related to the occurrence of the disease and decreased survival.

The pathophysiology of NEC is multifactorial and not precisely defined. However, it is related to immature innate immunity of newborn intestine and exaggerated inflammatory response [4]. Probiotics are defined as 'live microorganisms which when administered in adequate amount provide a health benefit to the host' [5]. The term

Manuscript received: $25^{\text {th }}$ October 2016

Reviewed: $8^{\text {th }}$ November 2016

Author Corrected; $20^{\text {th }}$ November 2016

Accepted for Publication: $30^{\text {th }}$ November 2016 
probiotic means 'for life' in Greek language as it was initially described as growth promoting factor. Further studies suggest that, they modulate intestinal microbiota of human beings [6]. Prebiotics are undigested nutrients that affect the host by promoting growth and /or activity of commensal microorganisms in large gut [5]. Subsequently the concept of synbiotics developed as both probiotics and prebiotics have potential synergy in the intestine, providing more potent benefit to the host than either administered alone [7].

Diversity of colonization pattern in newborns- Fetal intestine is sterile and colonization starts at delivery with maternal colonic and bacterial flora. Subsequent enteral feeding and environmental factors affects colonization. The pattern changes according to the type of delivery (spontaneous vaginal delivery/ caesarean section), maturity of baby, feeding (human milk / formula), administration of antibiotics and drugs acting on gastrointestinal tract [8]. Newborns delivered vaginally have more Bifidobacterium and Lactobacillus species and colonization with these beneficial microorganisms [9]. Caesarean delivery babies are more often associated with colonization of pathogenic bacteria like Clostridia, Klebsiella and Enterobacter [4].

Colonization with non-pathogenic diverse organisms such as Bifidobacteria and Lactobacillus is seen in healthy term babies [2]. The process of colonization in preterm and low birth weight is delayed, less diverse and with a pattern predominating pathogenic microbiome such as Staphylococci, coliforms, and bacteroids [8, 9]. Bifidobacterium and Lactobacillus are the principal kinds of commensal bacteria found in breast fed babies [2,9]. In formula-fed infants potentially harmful bacterial colonization such as Coliforms, Enterococci, Clostrium and Bacteroids predominate [6, 10]. The compromised gut microbiome of preterm due to broad-spectrum antibiotics and NICU environment become more pathogenic due to immature intestinal epithelial barrier and immunity [8].

Why preterm babies are more vulnerable to NEC- Gastrointestinal tract of preterm babies have immature peristaltic, digestive function along with deficient immunological and defence activities [8]. Secretory immunoglobulin A (Ig A) is also deficient in preterm babies. An inadequate digestive enzyme in mucus leads to defective digestion of proteins and carbohydrates [11]. Intestinal colonization with beneficial microorganisms is delayed in preterm neonates and pathogenic bacterial colonization predominates [4, 8]. Administration of broad spectrum antibiotics and other drugs in intensive care units change the microflora of preterm gut, colonize it with pathogenic microorganisms and again delays commensal bacterial colonization [4, 11]. Avoidance of breast milk to very low birth weight (VLBW) babies in many neonatal intensive care units (NICU) in early days of life causes lack of exposure to IgA, macrophages and other protective substances $[8,11]$.

Immune and inflammatory mechanism predisposing preterm neonates for NEC- Most common association of NEC is with prematurity. An underdeveloped immune system in preterm baby is inadequate for protection towards pathogenic microorganisms. As compared to term babies, the preterm babies show abnormal intestinal colonization pattern in NICU [6]. Delayed initiation of enteral feeding in NICU and administration of antibiotics and other drugs having effect on intestinal tract change the immunity and defence barrier [8]. Immaturity of preterm intestine include abnormal peristalsis, low gastric acidity, composition of mucus, increased permeability of mucosa, decreased secretory $\operatorname{IgA}$, immune defence and anti-inflammatory control [4,8]. Feeding and pathogenic bacterial colonization in gut leads to increased inflammatory response [6]. Decreased motility, increased permeability and compromised defence and immunity of gut leads to bacterial translocation [8]. This will cause haematogenous and lymphatic spread of bacteria across the intestine into systemic circulation, leading to systemic sepsis.

Gradual study in the field of NEC identified the role of Toll like receptors (TLR) in the pathogenesis of the disease. TLRs are glycoproteins and are important components of innate immune response [12]. TLR4 is an important member of TLR and is the receptor for bacterial lipopolysaccharide (LPS). Newborn intestine colonized with gram negative bacteria, having LPS in its membrane is usually followed by NEC. So an important role of TLR4 in the pathogenesis of NEC was suspected and latter on a number of evidences confirmed the suspicion [13, 14].

TLR4 is activated in response to hypoxia, ischemia and infection [12, 13]. TLR4 activation causes mucosal injury, enterocyte apoptosis and decreased epithelial repair [14]. As compared to term babies, preterm babies have increased TLR4 levels due to underdeveloped intestine and TLR4 is also more active $[14,15]$. Platelet activating factor (PAF), 
which is an inflammatory mediator in preterm gut can also activate TLR4 [9]. This will cause hyper-responsiveness of intestinal flora and induce a pro-inflammatory state in the pre-existing immature intestine. PAF is released in response to hypoxia, infection, or local injury and cause excessive bacterial activation of gut inflammatory response by up-regulating TLR4 [10].

Role of probiotics in decreasing the severity of NEC- The protective role of probiotics in intestinal sepsis include: (a) improving mucus secretion (b) maintaining intestinal barrier integrity (c) facilitating gut maturity (d) competitive inhibition of pathogenic microorganisms (e) keeping balance between pathogenic and commensal microbes. Exposure of neonatal intestinal epithelium to commensal bacteria limits the inflammatory process following pathogenic invasion and innate immunity is not activated [6]. Combination of probiotic organisms could be more effective and reliable than single strain $[11,12]$

TLR4 up-regulation predisposes to NEC development and increases severity of NEC [15]. TLR9 is another member of TLR and it recognizes bacterial DNA rich in CpG groups. Decreased TLR9 expression is detected in NEC babies [12]. Activation of TLR9 (homologue of TLR4) by CpG-DNA leads to decreased TLR4 signaling. Probiotics are rich in bacterial DNA and TLR9 recognizes the CpG motifs of DNA. CpG-DNA activates TLR9, thereby inhibiting TLR4 signaling. This will decrease enterocyte apoptosis, reduced cytokine production, thereby attenuating the severity of NEC $[12,13]$.

Probiotics compete with other pathologic organisms for binding sites and substrate in the intestine. It reduces proinflammatory cytokines, intestinal permeability and enhances anti-inflammatory cytokine production [16]. Acidic end product during metabolism of Lactobaccilus and Bifidobacterium lower the $\mathrm{pH}$ of gut and is unsuitable for pathogenic growth [11]. The probiotic Bifidobacterium bifidum decreases epithelial cell death by up-regulating TLR2 [10]. Immunological effects differ according to probiotic strain and also bacteria of same species [4]. Pathogenic bacterial colonization of gut and inadequate protection due to insufficient commensal bacteria leads to pathogenic overgrowth and bacterial translocation [6]. Probiotics secrete antibiotic molecules which reduce proliferation of pathogenic organisms. By competing with glycoconjugate on enterocyte surface, probiotics prevent adherence of pathological microorganisms [6]. Probiotics modulate immunoglobulin production. Secretory IgA have an important role in mucosal immunity,which acts as an barrier for harmful bacteria and viruses. Increase in number of IgA producing cells was found to be induced by probiotic bacteria [2].

Mucus production in intestine, not only acts as physiological barrier, but also helps in bacterial clearance. Probiotics may increase mucus secretion due to induction of mucin genes [9]. Lactobacillus induces expression of mucin genes MUC-2 and MUC-3 in cell culture models using HT-29 epithelial cells of intestine [17]. Pathogenic organisms were less adherent to probiotic treated cells. Lactobacillus binds to gut epithelial cells and mucins and might reverse the permeability of intestine [18]. Probiotic mixture containing Bifidobacterium, Lactobacillus and Streptococcus thermophilus (VSL \#3) induces MUC-2 gene expression and mucin secretion in animal models [19]. B. infantis conditioned medium is more effective in modulating inflammatory response in immature enterocytes than L. acidophilus conditioned medium. There is a possibility of soluble probiotic secretion attributing towards prevention of NEC and the secreted anti-inflammatory factor may be glycan or glycolipid [3]. Further studies are required to find out the physiochemical properties and structure of effective secreted factors.

Evidences supporting probiotics in prevention of NEC- The first study using combination of probiotics (Lactobacillus and Bifidobacterium infantis) mentioned significant decrease in incidence of NEC in preterm infants [20]. Further studies conducted by Bin-Nun et al [21] and Lin et al [22, 23] revealed similar results along with reduced severity of NEC and death. An Indian study suggested decreased incidence of NEC in VLBW neonates and hospital stay along with time to reach full feeds [24]. Although Rough et al failed to find beneficial effects of probiotics in extremely VLBW infants $(<1000 \mathrm{gm})$, they detected definite advantage of probiotics in infants $>1000 \mathrm{gm}$ [25].

Studies conducted by using single strain of probiotic, Lactobacilli reveal no significant decrease in NEC incidence and severity over control group [26, 27]. However an Italian study reported reduction in incidence of NEC in infants treated with Lactobacillus $G G$ [28]. But these infants also received bovine lactoferrin supplementation, which might have partly 
contributed to the outcome. Routine use of probiotic, Lactobacillus $G G$ is microbiologically safe and clinically well tolerated [29]. They tried Lactobacillus $G G$ starting from $4^{\text {th }}$ day and continued for at least 4 weeks. A combination of probiotic strains are needed for protection against the disease.

In the first major meta-analysis, Despande et al published encouraging results on probiotics [30]. They conducted the review on 11 randomized controlled trials (RCT) between 1997 and 2009 containing 2176 neonates.

Enteric probiotic supplementation started on preterm VLBW neonates (Birth weight $<1500$ gm and $<34$ week gestation) within first 10 days and continued for at least 7 days. The primary outcome was efficacy of probiotics in preventing stage II NEC or higher (modified Bell's staging criteria).

The risk for NEC and death was significantly lower in probiotic group as compared to control group. There was $30 \%$ reduction in NEC incidence ( $\alpha=0.05$ and 0.01 ; power: $80 \%$ ). No significant adverse effects of probiotics were reported. More recent Cochrane database review was published by Alfaleh et al in 2011 [31]. This meta-analysis enrolled preterm infants $<37$ weeks gestational age or $<2500$ gm birth weight or both.

Trials were included if they involved enteral administration of any live microbial supplement. Twenty-four eligible trials were included. Authors concluded that enteral supplement of probiotics prevent severe NEC (stage II or more) and all cause of mortality in preterm infants.

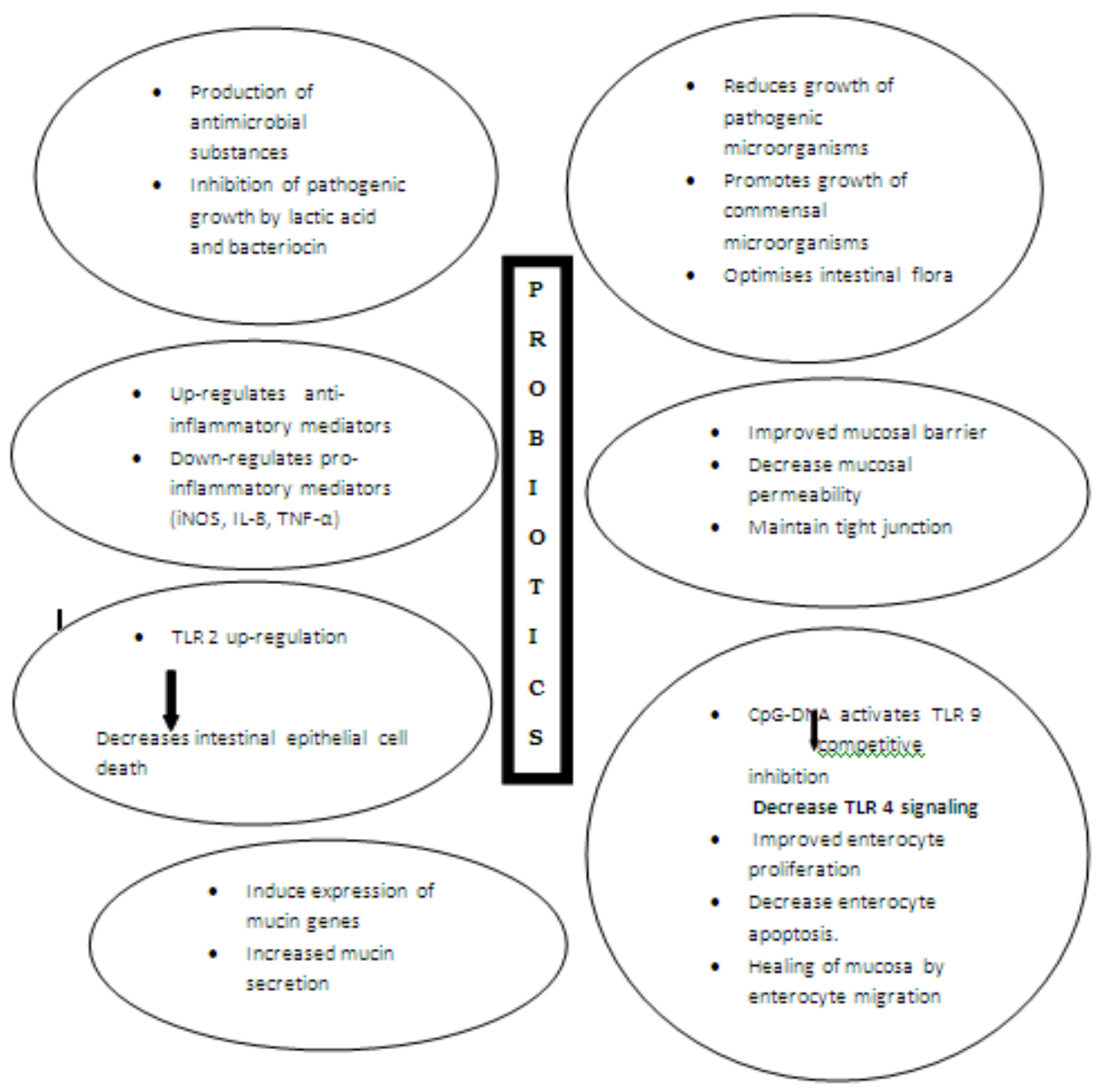

Figure-1: Mechanism of action of probiotics in prevention of NEC 
Review Article

\begin{tabular}{|c|c|c|c|c|c|c|}
\hline $\begin{array}{c}\text { Sl } \\
\text { No }\end{array}$ & Study/Year & $\begin{array}{c}\text { Probiotic } \\
\text { supplementation } \\
\text { (dosage \& duration) }\end{array}$ & Study group & Result & Conclusion & $\begin{array}{l}\text { Ref } \\
\text { ere } \\
\text { nce }\end{array}$ \\
\hline 1. & $\begin{array}{c}\text { Hoyos et al, } \\
\text { 1999, } \\
\text { Columbia, } \\
\text { (single centre) }\end{array}$ & $\begin{array}{l}\text { Lactobacillus } \\
\text { acidophilus, }\left(0.25 \times 10^{9}\right. \\
\text { CFU }) \text {, Bifidobacterium } \\
\text { infantis }\left(0,25 \times 10^{9} \mathrm{CFU}\right.\end{array}$ & $\begin{array}{c}<37 \mathrm{wk}, \\
1237 \\
\text { neonates, } \\
\text { admitted in } \\
\text { ICU vs } 1282 \\
\text { historical } \\
\text { control }\end{array}$ & $\begin{array}{c}3 \% \text { from } \\
\text { probiotic } \\
\text { group(no-37) } \\
\text { and } 6.6 \% \text { from } \\
\text { control } \\
\text { group(no-85) } \\
\text { developed } \\
\text { NEC }\end{array}$ & $\begin{array}{l}\text { Significant decrease in } \\
\text { NEC incidence in } \\
\text { probiotic group }\end{array}$ & 20 \\
\hline 2. & $\begin{array}{l}\text { Dani et al, } \\
\text { 2002, } 12 \\
\text { NICUs in } \\
\text { Italy, } \\
\text { (multicentre, } \\
\text { prospective } \\
\text { study) }\end{array}$ & $\begin{array}{c}\text { Lactobacillus } \\
\text { rhamnosus, GG } \\
6 \times 10^{9} \mathrm{CFU} \text {, once daily }\end{array}$ & $\begin{array}{c}<33 \text { wks and } \\
<1500 \text { gm } \\
295 \mathrm{in} \\
\text { probiotic } \\
\text { group vs } 290 \\
\text { in placebo }\end{array}$ & $\begin{array}{c}1.4 \% \text { in } \\
\text { probiotic group } \\
\text { (no-4) vs } 2.8 \% \\
\text { (no-8) control } \\
\text { group (non } \\
\text { significant } \\
\text { decrease in } \\
\text { NEC } \\
\text { incidence) }\end{array}$ & $\begin{array}{c}\text { Lactobacillus } \\
\text { rhamnosus GG } \\
\text { supplementation is not } \\
\text { effective in decreasing } \\
\text { incidence of NEC }\end{array}$ & 26 \\
\hline 3. & $\begin{array}{c}\text { Lin et al, } \\
\text { 2005, Taiwan, } \\
\text { single- centre, } \\
\text { prospective } \\
\text { study }\end{array}$ & $\begin{array}{c}\text { Lactobacillus } \\
\text { acidophilus, B. Infantis } \\
10^{6} \text { organisms twice } \\
\text { daily from } 7^{\text {th }} \text { day till } \\
\text { discharge }\end{array}$ & $\begin{array}{l}<1500 \mathrm{gm}, \\
180 \mathrm{in} \\
\text { probiotic } \\
\text { group vs } \\
187 \text { in } \\
\text { control group }\end{array}$ & $\begin{array}{c}1.1 \% \text { in } \\
\text { probiotic group } \\
\text { (no-2) } 5.3 \% \text { in } \\
\text { control group } \\
\text { (no-10) }\end{array}$ & $\begin{array}{l}\text { Significant decrease in } \\
\text { NEC incidence, } \\
\text { severity and death }\end{array}$ & 22 \\
\hline 4. & $\begin{array}{l}\text { Bin-Nun et al, } \\
\text { 2005, Israel, } \\
\text { single centre } \\
\text { study }\end{array}$ & $\begin{array}{c}\text { Bifidobacterium } \\
\text { infantis } \\
\text { Bifidobacterium } \\
\text { bifidus, Streptococcus } \\
\text { thermophilus } 0.35 \times 10^{9} \\
\text { CFU each once daily } \\
\text { from first feed up to } \\
\text { gestational age } 36 \mathrm{wks}\end{array}$ & $\begin{array}{l}<1500 \mathrm{gm}, \\
\text { preterm } \\
\text { infants, } 72 \text { in } \\
\text { probiotic } \\
\text { group, } 73 \text { in } \\
\text { control group }\end{array}$ & $\begin{array}{c}4 \% \text { in } \\
\text { probiotic group } \\
\text { vs } 16.4 \% \text { in } \\
\text { control group }\end{array}$ & $\begin{array}{c}\text { Significant reduction } \\
\text { in NEC incidence and } \\
\text { severity }\end{array}$ & 21 \\
\hline 5. & $\begin{array}{c}\text { Lin et al, } \\
\text { 2008, Taiwan, } \\
\text { seven NICUs } \\
\text { multi-centre } \\
\text { study }\end{array}$ & $\begin{array}{c}\text { Bifidobacterium } \\
\text { bifidum, Lactobacillus } \\
\text { acidophilus twice daily } \\
\text { for } 6 \mathrm{wks}\end{array}$ & $\begin{array}{c}<1500 \text { gm, } \\
217 \text { in study } \\
\text { group vs } 217 \\
\text { in control } \\
\text { group }\end{array}$ & $\begin{array}{l}1.8 \% \text { (no- } 4 \text { ) in } \\
\text { study group vs } \\
6.5 \% \text { (no-14) } \\
\text { in control } \\
\text { group }\end{array}$ & $\begin{array}{c}\text { Reduced incidence of } \\
\text { death and severity of } \\
\text { NEC }\end{array}$ & 23 \\
\hline 6. & $\begin{array}{l}\text { Samanta et al, } \\
\text { 2009, India, } \\
\text { single centre }\end{array}$ & $\begin{array}{c}\text { Bifidobacterium } \\
\text { infantis, } \\
\text { Bifidobacterium } \\
\text { bifidum, } \\
\text { Bifidobacterium } \\
\text { longum and } \\
\text { Lactobacillus } \\
\text { acidophilus } 2.5 \times 10^{9} \\
\text { CFU each twice daily } \\
\text { until discharge }\end{array}$ & $\begin{array}{l}<34 \mathrm{wk}, \\
<1500 \mathrm{gm}, \\
91 \mathrm{in} \\
\text { probiotic } \\
\text { group, } 95 \mathrm{in} \\
\text { control group }\end{array}$ & $\begin{array}{l}5.5 \% \text { in } \\
\text { probiotic group } \\
\text { (no-5), } 15.8 \% \\
\text { in control } \\
\text { group(no-15), } \\
\text { decrease in } \\
\text { NEC incidence } \\
\text { and sepsis }\end{array}$ & $\begin{array}{l}\text { Prophylactic probiotic } \\
\text { supplementation } \\
\text { reduced incidence of } \\
\text { NEC, shortened time } \\
\text { to reach full feeds and } \\
\text { decreased duration of } \\
\text { hospital stay }\end{array}$ & 24 \\
\hline
\end{tabular}


Review Article

\begin{tabular}{|c|c|c|c|c|c|c|}
\hline 7. & $\begin{array}{l}\text { Braga et al, } \\
2011 \text {, Brazil, } \\
\text { single centre }\end{array}$ & $\begin{array}{c}\text { Bifidobacterium breve, } \\
\left(3.5 \times 10^{7} \text { to } 3.5 \times 10^{9}\right. \\
\text { CFU), Lactobacillus } \\
\text { casei from } 2^{\text {nd }} \text { day of } \\
\text { life until } 30 \text { day of } \\
\text { life or discharge or } \\
\text { death }\end{array}$ & $\begin{array}{l}750 \text { gm to } \\
1499 \text { gm } 119 \\
\text { in probiotic } \\
\text { group, } 112 \text { in } \\
\text { control group }\end{array}$ & $\begin{array}{c}\text { None in } \\
\text { probiotic } \\
\text { group, } 3.6 \% \text { in } \\
\text { control, group } \\
\text { (No-4). } \\
\text { Probiotic } \\
\text { group achieved } \\
\text { full enteral } \\
\text { feed faster than } \\
\text { control group }\end{array}$ & $\begin{array}{l}\text { Use of probiotics had } \\
\text { a beneficial effect on } \\
\text { occurrence of NEC }\end{array}$ & 32 \\
\hline 8. & $\begin{array}{l}\text { Sari et al, } \\
2011, \text { Turkey, } \\
\text { prospective, } \\
\text { single centre } \\
\text { trial }\end{array}$ & $\begin{array}{c}\text { Lactobacillus } \\
\text { sporogens, }\left(3.5 \times 10^{8}\right. \\
\text { CFU), once a day from } \\
\text { first feed until } \\
\text { discharge }\end{array}$ & $\begin{array}{l}<1500 \text { gm, } \\
<33 \mathrm{wks}, \\
110 \mathrm{in} \\
\text { probiotic } \\
\text { group, } 111 \mathrm{in} \\
\text { control group }\end{array}$ & $\begin{array}{c}5.5 \% \text { in } \\
\text { probiotic group } \\
\text { (no-6), } 9 \% \text { in } \\
\text { control } \\
\text { group(no-10) }\end{array}$ & $\begin{array}{c}\text { No significant } \\
\text { difference in incidence } \\
\text { of death or NEC } \\
\text { between the groups. } \\
\text { Lactobacillus } \\
\text { sporogens improved } \\
\text { feeding tolerance }\end{array}$ & 27 \\
\hline 9. & $\begin{array}{l}\text { Rouge et al, } \\
\text { 2009, France, } \\
\text { Two centre } \\
\text { study }\end{array}$ & $\begin{array}{l}\text { Bifidobacterium } \\
\text { longum, Lactobacillus } \\
\text { rhamnosus GG } 10^{8} \\
\text { CFU, once daily till } \\
\text { discharge }\end{array}$ & $\begin{array}{c}\text { Gestational } \\
\text { age }<32 \text { wks, } \\
\text { birth weight } \\
<1500 \mathrm{gm} . \\
45 \text { in } \\
\text { probiotic } \\
\text { group and } 49 \\
\text { in control } \\
\text { group }\end{array}$ & $\begin{array}{c}4.4 \% \text { in } \\
\text { probiotic group } \\
\text { (no-2) and } 2 \% \\
\text { in control } \\
\text { group (no-1), } \\
\text { primary } \\
\text { outcome did } \\
\text { not differ } \\
\text { between two } \\
\text { groups }\end{array}$ & $\begin{array}{l}\text { Time to reach full } \\
\text { feeds is significantly } \\
\text { shorter in probiotic } \\
\text { group in infants }> \\
1000 \text { gm (beneficial } \\
\text { effect was observed) }\end{array}$ & 25 \\
\hline 10. & $\begin{array}{l}\text { Manzoni et al, } \\
\text { 2011, Italy, } \\
\text { multi-centre } \\
\text { trial }\end{array}$ & $\begin{array}{c}\text { Lactobacillus } \\
\text { rhamnosus, GG } 3 \times 10^{9} \\
\text { CFU/day single oral } \\
\text { dose since } 4^{\text {th }} \text { day of } \\
\text { life for } 4 \text { to } 6 \mathrm{wks}\end{array}$ & $\begin{array}{c}\text { Six year } \\
\text { cohort study } \\
\text { on } 743 \\
\text { VLBW } \\
\text { infants }\end{array}$ & $\begin{array}{c}1.9 \% \text { (No-14) } \\
\text { of cases } \\
\text { developed } \\
\text { NEC. No } \\
\text { clinical sepsis } \\
\text { episodes were } \\
\text { attributed to } \\
\text { LGG }\end{array}$ & $\begin{array}{c}\text { Routine } \\
\text { supplementation of } \\
\text { probiotic, LGG is } \\
\text { microbiologically safe } \\
\text { and clinically well } \\
\text { tolerated }\end{array}$ & 29 \\
\hline
\end{tabular}

After publication of Cochrane meta-analysis, a double-blind, randomized, controlled clinical trial conducted on 231 preterm infants in Brazil having birth weight between 750 to $1499 \mathrm{gm}$ [32]. The objective was to find out whether combined use of Lactobacillus casei and Bifidobacterium breve can prevent NEC (Bell's modified stage $>2$ ). They detected only four confirmed cases of NEC in control group. Authors summarized that combined supplementation of the above probiotics reduced the occurrence of NEC (stage $>2$ ) in VLBW infants.

Another meta-analysis published in 2012, searched PUBMED, Embase along with Chinese biomedical literature database, which was not covered in previous meta-analysis reports [33]. They included 20 RCTs with a total of 3816 preterm VLBW infants.

The probiotic supplements were found to be associated with a significantly deceased risk of NEC and mortality. In a recent meta-analysis authors considered databases from MEDLINE, Embase and LILACS Eleven randomized trials totaling 2887 preterm neonates were included [34]. There was a reduction in incidence of NEC, neonatal sepsis and overall death. 
Prebiotics- Prebiotics are undigested nutrients that affect the host by promoting growth and/or activity of commensal microorganisms in large intestine [5]. The nutrient: (a) should not be absorbed in small intestine, (b) should stimulate only the beneficial microorganisms, (c) inhibit growth of pathogenic bacteria and change the colonic flora towards healthy pattern [35]. The prebiotic oligosaccharide present in breast milk can stimulate Lactobacilli and Bifidobacterial colonization in large gut of infants [5]. There are > 100 specific types of oligosaccharide molecules in human milk, which bind to specific organisms and provide host defense [36]. An analysis of 4 RCTs was conducted with total number of 126 preterm babies. The oligosaccharide supplementation in these babies was galactooligosaccharide and/or fructooligosaccharide for 14 to 33 days. The studies suggested increased colony counts of Lactobacilli and Bifidobacteria in preterm infants without any adverse effect [5]. Prebiotic oligosaccharide supplementation is considered to decrease the incidence of NEC and sepsis [41]. So there is a rationale to use in preterm neonates for NEC prevention [36]. The concept of prebiotics exist since last 20 years with an advantage that, these are food ingredients and not live bacteria. A potential synergy has been mentioned between probiotic and prebiotic effect in the intestine. So the combination is often described as synbiotics. Authors consider the synbiotic effect to be more beneficial than individual probiotic or prebiotic $[7,35]$.

Postbiotics and Antibiotics- Postbiotics are metabolites of bacteria having potential benefit in NEC by stimulating commensal microbial flora in intestine [5, 12]. A short-chain fatty acid, butyric acid is one such metabolite having beneficial role in human large gut [41]. However, further investigation is required to prove its function in NEC infants. Several studies have been conducted on the effect of enteral antibiotics in NEC babies. A meta-analysis conducted suggests significant decrease in the incidence of NEC and death [42]. But authors also mention increased colonization of resistant bacteria [5] and there are chances of fungal growth. The available evidences till date do not support routine enteral prophylaxis in NEC.

\section{Conclusion}

NEC is one of the commonest causes of death in preterm infants and long term disability in survivors. The pathogenesis of the disease is complex, multifactorial and partly understood. However it is related to immature innate immunity of newborn intestine and exaggerated inflammatory response. The crucial role of innate immune receptor 'Toll-like receptor' has been established in the pathogenesis of the disease. So a novel therapeutic approach for NEC by selective silencing of TLR within newborn intestinal epithelium is needed to prevent the disease. Probiotics are rich in bacterial DNA and can provide therapeutic benefit to neonates affected by NEC. Several RCTs detected beneficial role of probiotics in prevention of the disease in low birth weight infants.

Individual probiotic strains of bacteria vary in their ability to prevent NEC, but combination of strains definitely gives beneficial result without adverse effect. They are safe, effective, easy to administer and should be used routinely in NEC prophylaxis.

However, further research is needed on optimal strain type, dose, timing and length of therapy to provide a best preparation. Synbiotics, a combination of probiotics and prebiotics can offer more promising outcome than either of them alone. This review highlights implications of using probiotics, prebiotics and synbiotics as a strategy to prevent NEC and issues that need to be encountered in prescribing preparations. The pathogenesis of the disease and molecular-specific therapy by targeting toll-like receptors are considered, which will provide new insight for protecting the tiny neonates from the devastating disease.

\section{Funding: Nil, Conflict of interest: Nil Permission from IRB: Yes}

\section{References}

1. Alison Chu, Joseph R. Hageman and Michael S. Caplan Necrotizing Enterocolitis: Predictive Markers and Preventive Strategies. Neo Reviews. 2013; 14; e113 DOI: 10.1542/neo.14-3-e113.

2. Sari FN, Dilmen U. Probiotic Use for Prevention of Necrotizing Enterocolitis in Preterm Infants. (c) 2012 Sari and Dilmen, licensee InTech. http://dx. doi.org/10. 5772/50049. Downloadedfrom http: //www. intechopen. com/download/ pdf/39601

3. Kriston G, Meng Di, Rautava S, Lu L, Walker WA, Nanthakumar N. Probiotics prevent necrotizing enterocolitis by modulating enterocyte genes that regulate innate immune -mediated inflammation. Am J Physiol Gastrointest Liver Physiol.2013 Jan 15. 304(2); G132-G141. DOI: 10.1152/ajpgi.00142.2012. 
4. Ganguli K, Meng D, Rautava S, Lu L, Walker WA, Nanthakumar N. Probiotics prevent necrotizing enterocolitis by modulating enterocyte genes that regulate innate immune-mediated inflammation. Am J Physiol Gastrointest Liver Physiol. 2013 Jan 15;304 (2):G132-41. doi: 10.1152/ajpgi.00142.2012. Epub 2012 Nov 8.

5. Patel B, Shah JS. Necrotozing Enterocolitis in Very Low Birth Weight Infants: A Systematic Review. ISRN Gastroenterol. 2012; 2012:562594. Published online 2012 Sep 10. DOI: 10.5402/2012/562594.

6. Chen CC, Walker A. Probiotics and the mechanism of necrotizing enterocolitis. Seminars in Pediatric Surgery.2013; 22:94-100. doi: 10.1053/j.sempedsurg. 2013.01.006

7. Johnson-Henry KC, Abrahamsson TR, Wu RY, Sherman PM. Probiotics, Prebiotics and Synbiotics for the Prevention of Necrotizing Enterocolitis. Adv Nutr. 2016 Sep 15;7(5):928-37. doi: 10.3945/an.116.012237. Review.PMID:27633108.

8. Qasem W Alnaqi A, Jorgensen S, Friel J. Probiotic and Synbiotics in Necrotizing Enterocolitis: Where Are We? J Pediatr Neonatal Care 2014; 1(1): 00007. DOI: 10.15406/jpnc.2014.01.00007.

9. Frost BL, Caplan MS. Necrotizing Enterocolitis: Pathophysiology, platelet-activating factor, and probiotics. Semin Pediatr Surg. 2013May;22(2):8893. doi: 10.1053/j.sempedsurg.2013.01.005.

10. Heather J.L. Brooks, Michelle A. McConnell and Roland S. Broadbent (2013). Microbes and the Inflammatory Response in Necrotising Enterocolitis, Preterm Birth, Dr. Offer Erez (Ed.), InTech, DOI: 10.5772/55039. Available from: http://www. intechopen. com/ books/preterm-birth/ microbesand-the-inflammatory-response-in-necrotisingenterocolitis.

11. Niekerk V. Probiotics in premature infants: focus on necrotizing enterocolitis. S Afr J CLin Nutr. 2011; 24(3):S35-S37. Access from http:/www.ajol. Info /index. php/sajcn/article/viewFile/69809/57892.

12. Tripathy PK, Nanda R. Management Modalities for Necrotizing Enterocolitis: Targeting Toll-Like Receptors. AABS. 2016; 3(1): R1-R5. e-ISSN: 23496991; p-ISSN: 2455-0396.
13. Afrazi A, S Sodhi CP, Richardson W, Neal M, Good M, Siggers R, Hackam D. New Insights Into the Pathogenesis and Treatment of Necrotizing Enterocolitis: Toll- Like Receptors and Beyond. Pediatric Research. 2011Mar; 69(3): 183-8. DOI: 10. 1203/PDR.0b013e3182093280.

14. De Curtis M, Terrin G. Necrotizing enterocolitis (NEC) what's going on. Journal of Pediatric and Neonatal Individualized Medicine 2013;2(2):e020218 doi: 10.7363/020218 Advance publication: 2013 Aug 21.

15. Hackam DJ, Afrazi A, Good M, Sodhi CP. Innate Immune Signaling in the Pathogenesis of Necrotizing Enterocolitis. Clin Dev Immunol. 2013;2013: 475415. DOI: 10. 1155 / 2013 / 475415. Epub 2013 May 23.

16. Soll RF. Probiotics: are we ready for routine use? Pediatrics 2010:125:1071-1072. doi: 10.1542/peds. 2010-0643. pmid: 20421256 Epub 2010 Apr 26.

17. Mack DR, Michail S, Wei S, McDougall L, Hollingsworth MA. Probiotics inhibit enteropathogenic $E$. coli adherence in vitro by inducing intestinal mucin gene expression. Am J Physiol. 1999 April;276(4 Pt 1): G941-G950.

18. Hunter CJ, Upperman JS, Ford HR, Camerini V. Understanding the susceptibility of the premature infant in Necrotizing Enterocolitis(NEC). Pediatr Res 2008; 63:117-123. DOI:10.1203/PDR.0b013e31815ed64c

19. Caballero-FrancoC, KellerK, De Simonne C, Chadee K. The VSL\#3 probiotic formula induces mucin gene expression and secretion in colonic epithelial cells. AM J Physiol Gastrointest Liver. January2007; 292:G315-G322 doi:10.1152/ajpgi.00265.2006.

20. Hoyos AB. Reduced incidence of necrotizing enterocolitis associated with enteral administration of Lactobacillus acidophilus and Bifidobacterium infantis to neonates in the intensive care unit. Int J Infect Dis. 1999; 3(4): 197-202.

21. Bin-Nun A, Bromiker R, Wilschanski M, Kaplan M, Rudensky B, Caplan M, Hammerman C. Oral probiotics prevent necrotizing enterocolitis in very low birth weight neonates. J Pediatr. 2005 Aug;147(2):192196. DOI:10.1016/j.jpeds.2005.03.054. 
22. Lin hc, su bh, chen ac, lin tw, tsai ch, yeh tf, oh w. Oral probiotics reduce the incidence and severity of necrotizing enterocolitis in very low birth weight infants. Pediatrics. 2005;115(1):1-4. Doi:10.1542/ peds. 2004-1463.

23. Lin hc, hsu ch, chen hl, chung my, hsu jf, lien ri, et al. Oral probiotics prevent necrotizing enterocolitis in very low birth weight preterm infants: a multicentre, randomized, controlled trial. Pediatrics 2008;122: 693 700. Doi: 10.1542/peds.2007-3007.

24. Samanta M, Sarkar M, Ghosh P, Ghosh JK, Sinha MK, Chatterjee S. Prophlactic probiotics for prevention of necrotizing enterocolitis in very low birth weight newborns. J Trop Pediatr.2009Apr, 55(2) :128131. DOI: 10.1093 /tropej /fmn091. Epub 2008 Oct 8 .

25. Rouge C, Piloquet H, Butel MJ, Berger B, Rochat Fllorence, Ferraris L, et al. Oral supplementation with probiotics in very-low-birth-weight preterm infants: a randomized, double-blind, placebo-controlled trial. Am J Clin Nutr.2009;89(6) ;1828-35. doi: 10.3945/ajen. 2008.26919. Epub 2009 Apr 15.

26. Dani C, Biadaioli R, Bertini G, Martelli E, Rubaltelli FF. Probiotics feeding in prevention of urinary tract infection, bacterial sepsis and necrotizing enterocolitis in preterm infants. A prospective double blind study. Biol Neonate. 2002;82:103-108.DOI:10. 1159/000063096.

27. Sari FN, Dizdar FA, Oguz S, Erdeve O, Uras N, Dilmen U. Oral probiotics: Lactobacillus sporogenes for prevention of necrotizing enterocolitis in very lowbirth weight infants: A randomized, controlled trial. Eur J Clin Nutr. 2011 Apr;65(4):434-439. doi: 10.1038/ejcn. 2010. 278. Epub 2011 Jan 19

28. Manzoni P, Rinaldi M, Cattani S, Pugni L, Romeo MG, Messner H, Stolfi I, et al. Decembrino L, Bovine lactoferrin supplementation for prevention of late-onset sepsis in very low birth neonates: A randomized trial. JAMA. 2009 Oct 7;302(13):1421-8. doi: 10.1001/jama.2009.1403.

29. Mazoni P, Lista G, Gallo E, Marangione P, Priolo C, Fontana P, Guardione R, Farina D. Routine lactobacillus rhamnosus GG administration in VLWL infants. Early Hum Dev. 2011 Mar; 87 Suppl
1:S35-8. doi: 10.1016/j.earlhumdev.2011.01.036. Epub $2011 \mathrm{Feb} 3$.

30. Deshpande G, Rao S, Patole S, Bulsara M. Updated Meta-analysis of Probiotics for Preventing Necrotizing Enterocolitis in Preterm Neonates. Pediatrics. 2010 May; 125 (5) : 921-30. doi: 10.1542/peds.2009-1301. Epub 2010 Apr 19.

31. AlFaleh K, Anabrees J. Probiotics for prevention of necrotizing enterocolitis in preterm infants. Cochrane Database Syst Rev. 2014 Apr 10;(4):CD005496. doi: 10.1002/14651858.CD005496.pub4.

32. Braga TD, da Silva GA, de Lira PI, de Carvalho Lima M. Efficacy of Bifidobacterium breve and Lactobacillus casei oral supplementation on necrotizing enterocolitis in very-low-birth-weight preterm infants: a double-blind, randomized, controlled trial. Am J Clin Nutr. 2011 Jan; 93(1):81-86. doi: 10.3945/ajen.2010. 29799. Epub 2010 Oct 27.

33. Wang Q, Dong J, Zhu Y. Probiotic supplement reduces risk of necrotizing enterocolitis and mortality in preterm very-low-birth-weight infants; an updated meta-analysis of 20 randomized controlled trials. J Pediatr Surg. 2012 Jan;47(1):241-8. doi: 10.1016/j. jpedsurg. 2011.09.064.

34. Bernado WM, Aires FT, Carneiro RM, Sa FP, Rullo VE, Burns DA. Effectiveness of probiotics in the prophylaxis of necrotizing enterocolitis in preterm neonates: a systematic review and meta-analysis. J Pediatr (RioJ). 2013;89:18-24.http://dx.doi.org/ 10. 1016/j.jped.2013.02.004.

35. Bandopadhyay B, Mandal NC, Probiotic, Prebiotics and Synbiotics - In Health Improvement by Modulating Gut Microbiota : The Concept Revisited. Int J Curr Microbiol App Sci.2014; 3(3): 410-420.

36. Caplan MS. Probiotic and prebiotic supplementation for prevention of neonatal necrotizing enterocolitis. J Perinatol. 2009 May;29 Suppl 2:S2-6. doi: 10. 1038/jp.2009.21

37. Boehm G, Lidestri M, Casetta $P$, et al. Supplementation of a bovine milk formula with an oligosaccharide mixture increases counts of fecal bifidobacteria in preterm infants. Archives of Disease in Childhood.2002;86(3):F178-F181. 
38. Mihatsch W, Hoegel J, Pohlandt F. Prebiotic oligosaccharides reduce stool viscosity and accelerate gastrointestinal transport in preterm infants. Acta Paediatrica. 2006;95(7):843-848.

39. Indrio F, Riezzo G, Montagna O, Valenzano E, Mautone A, Boehm G. Effect of a prebiotic mixture of short chain galacto-oligosaccharides and long chain fructo-oligosaccharides on gastric motility in preterm infants. Journal of Pediatric Gastroenterology and Nutrition. 2007;(article e122)

40. Kapiki A, Costalos C, Oikonomidou C, Triantafyllidou A, Loukatou E, Pertrohilou V. The effect of a fructo-oligosaccharide supplemented formula on gut flora of preterm infants. Early Human Development.2007;83(5):335-339. pub 2006 Sep 14.

41. Sylvester KG, Liu GY, Albanese CT. Necrotizing Enterocolitis. In Coran AG, Adzick NS, Krummel TM, Laberge J, Shamberger RC, Caldamone AA. Pediatric Surgery. $7^{\text {th }}$ Edn. Philadelphia: Elsevier Saunders, 2012. Chapter 94, p 1187-1207.

42. Bury RG, Tudehope D. Enteral antibiotics for preventing necrotizing enterocolitis in low birth weight or preterm infants. Cochrane Database Syst Rev. 2001; (1): CD000405. DOI: 10.1002/ 14651858. CD000405.

\section{How to cite this article?}

Tripathy PK, Nanda R.Necrotizing Enterocolitis: Probiotics, Prebiotics and Synbiotics for Prevention in Preterm Infants. Int. J PediatrRes.2016;3(11):856-865.doi:10.17511/ijpr.2016.i11.15. 